\title{
Effects of Informal Settlement Upgrading in Kabul City, Afghanistan: A Case Study of Afshar Area
}

\author{
Haroon Nazire, Michihiro Kita, Seth Asare Okyere, Shigeki Matsubara \\ Division of Global Architecture, Graduate School of Engineering, Osaka University, Osaka, Japan \\ Email: haroon.nazire@gmail.com
}

How to cite this paper: Nazire, H., Kita, M., Okyere, S. A., \& Matsubara, S. (2016). Effects of Informal Settlement Upgrading in Kabul City, Afghanistan: A Case Study of Afshar Area. Current Urban Studies, 4, 476494.

http://dx.doi.org/10.4236/cus.2016.44031

Received: November 4, 2016

Accepted: December 25, 2016

Published: December 28, 2016

Copyright $\odot 2016$ by authors and Scientific Research Publishing Inc. This work is licensed under the Creative Commons Attribution International License (CC BY 4.0).

http://creativecommons.org/licenses/by/4.0/

(c) (i) Open Access

\begin{abstract}
Rapid migration and vast urban expansion have contributed to large informal settlements in Kabul city. Post-war refugees, the return of internally displaced residents to the city, and rural migration are some causal factors. About 69 percent of the city's population live in informal settlements. This growth together with a volatile security situation and limited local government capacity has overwhelmed municipal authorities. To address the challenges of informal settlements in the Kabul city, the Afghan government with support from international organizations has recently implemented a settlement-upgrading program. This paper focuses on understanding the effects of this upgrading program and resident's satisfaction with it using data from interviews conducted in the Afshar area of the city. Findings reveal that interventions under the program were unidimensional, often focusing on physical improvements. While these led to improved housing conditions, accessibility, and the local economy of $A f$ shar area, it does not integrate key social, economic and environmental issues. Moving forward, the article suggests the need to adopt integrated settlement upgrading to confront the challenge of informal settlements in Kabul city.
\end{abstract}

\section{Keywords}

Informal Settlements, Urban Upgrading, Houses Improvement, Kabul City

\section{Introduction}

The challenge of informal settlements remains a daunting task for city authorities and local governments in developing countries. Indeed, in this age of the city, informality dominates (Kudva, 2009) and it is estimated that about one billion people reside in informal settlements globally. Such settlements are growing fastest in Sub-Saharan Africa, Southeastern and Western Asia (World Bank, 2016). Thus, given the perpetual challenge of informal settlements, it attracts significant attention from international agencies, 
planning professionals, academics, and civil society.

Since it first emerged in the 1950/60s, there has been an explosion of research on urban informal settlements across academic disciplines including housing and urban development. This is particularly true for the subject of informal settlement upgrading (UN Habitat, 2003; Balbo, 2001; Imparato \& Ruster; 2003; Wegelin, 2004). Upgrading which first appeared as a favorable option to eviction/demolition of informal areas (Khalifa, 2015) concerns, at the basic level, improving the physical environment of a settlement (Wekesa et al., 2011). It has, however, evolved to integrate physical, social, economic, and environmental improvements undertaken collaboratively with local residents (Wekesa et al., 2011). Upgrading programs have been widely executed, from direct international and government initiatives in the late 1970s (Abbott, 2002) to community-based programs since the late 1990s (Weru, 2004; Galuszka, 2014). Thailand, Philippines, Pakistan, Kenya, South Africa and Colombia represent a few of these countries where such programs have been executed and analyzed in scholarly works. Indeed, a lot has been learned from the seeming failures (Gilbert, 2007) and locally based successes (Boonyabancha, 2005, 2009). Informality, in general, has been researched extensively but there is still a lot more to learn (Kudva \& Beneria, 2005).

In spite of these diverse studies on upgrading, there appears a gap in research on understanding the mechanism of upgrading and its effects in areas with vulnerable security situations and undergoing post-war urbanization. To this end, understanding the effects of upgrading programs in postwar urban settlements will contribute to the rich diversity of on-going scholarly work on the subject. It will also enhance existing knowledge on improving informal settlement conditions in areas scarcely considered in urban studies-areas with vulnerable security situations and undergoing post-war urbanization.

This paper provides an insight into the implementation and effects of the national upgrading program in Kabul city. Kabul city enables us to understand the dynamics of upgrading programs in volatile urban communities with urbanization and limited local government capacity. This paper focuses on the effects of upgrading programs and local resident's satisfaction with it. It is organized into three parts. The first emphasizes the conceptual notes in the work. The second part focuses on the upgrading program and the third part engages the effects of upgrading on housing, local economy and resident satisfaction.

\section{Conceptual Framework: Informal Settlements and Upgrading}

Informal settlements: this terminology is used to describe a wide range of low-income settlements or poor living conditions (UN Habitat, 2003). This diversity often implies complexity as it encompasses both progressive settlements, characterized by usually illegally self-built structures with a certain level of development, and declining neighborhoods in which environmental and domestic services are in continuous deterioration (UN Habitat, 2003). It is also referred to as 'bad' shelter or that which evolves outside planning order (Gilbert, 2007; Okyere \& Kita, 2015). In spite of the extensive de- 
bate in scholarly circles (Roy, 2011; Huchzermeyer, 2004; Davis, 2004; Okyere \& Kita, 2015) informal settlements are identified with characteristics including irregular land tenure, self-built housing and low level of infrastructure (Lombard, 2014; UN Habitat, 2003).

\subsection{Settlement Upgrading}

Informal settlement upgrading generally refers to any sector-based intervention that results in quantifiable improvement in the lives of people (Abbott, 2002). It is rooted in the work of housing scholar John Turner was promoted by the World Bank in its approach to informal settlements in the 1970s (World Bank, 1974; Lieberherr-Gardiol, 2006). It involves providing or improving basic infrastructure and services: water and sanitation, electricity, drainage, and roads (Acioly, 2002; Menshawya et al., 2011), and, more importantly, legalizing and regularizing insecure land tenure (Imparato \& Ruster, 2003).

In spite of the divergent opinions on the strategy of informal settlement upgrading (Smolka \& Bidderman, 2011; Okyere et al., 2016), it is highly favored-compared to demolition (Durand-Lasserve \& Royston, 2002) - and proven to be useful in community-led and integrated development interventions (Hasan, 2006; Weru, 2004; Burra, 2005).

It is important to stress that settlement upgrading has moved from the basic historical process of physical developments to encompass environmental, institutional and economic interventions (Wekesa et al., 2011). Again, there have been numerous cases of such upgrading interventions led by community organizations and federations with a certain local government involvement. In light of government apathy, ambivalence, and minimal involvement, it appears community-led upgrading has become widespread (see Weru, 2004).

A vast repository of literature exists on informal settlement upgrading across the world, especially in the context of developing countries. Khalifa (2015), for example, has reviewed the evolution of settlement upgrading in terms of change and policy in Egypt. Others (Weru, 2004; Abbott, 2002) have looked at specific base interventions in Kenya and South Africa, specifying seeming progress and challenges. Moreover, the effects of upgrading in terms of tenure security, community cohesion, and sanitation through community-based program exist for Pakistan, India, and Thailand (Burra, 2005; Boonyabancha, 2005, 2009).

In spite of these studies, which have provided critical information on best practices and effective mechanisms for settlement, there is a paucity of experiences in the case of Afghanistan. Upgrading in Afghanistan is more recent but the knowledge on its experiences and effects is limited. Turkstra and Popal (2010) provides useful information on the policy and implementation process in Afghanistan, but there is a little consideration to effects and resident perspectives. The UN-Habitat, as an urban think tank, has been instrumental in the informal settlement in Kabul, including upgrading. Beyond this, and few other reports from international agencies (e.g. JICA, 2011), there is little 
known on informal settlement upgrading in Kabul, where about 69 percent of the city is informal housing.

In view of the government's new policy on expanding informal settlement upgrading to most cities in Afghanistan, it is important to understand the current state of upgraded areas to provide lessons for new programs. This paper, therefore, seeks to contribute to the knowledge of settlement upgrading in Afghanistan by analyzing its effects on housing, local economy and residents satisfaction with the upgrading interventions.

\subsection{Kabul City and the Development of Informal Settlements}

Kabul city is the capital and the largest city in Afghanistan, and one of fastest growing cities in south Asia. Currently, there are some challenges with figures for the city's population due in part to its security situation. However, some available estimates put the city's population growth rate at 15 percent per annum from 1992 to 2002. In 2004, the total population of the city was estimated at 3 million inhabitants, an increase from 1.78 million in 1999 (Noori, 2010). The city had an approximately 6 million population in 2014 (The Guardian, 2014; Beall \& Esser, 2005).

This unprecedented urban population growth has been attributed to recent resurges in migration in the post-war years. Migration contributes about 40 percent to the city's population growth (Noori, 2010). This has intensified since 2001 after the fall of the Taliban regime.

There are two marked processes in the migration trends. First, people have overwhelmingly migrated from rural areas to Kabul in search of employment and other economic opportunities. Secondly, internally displaced persons and Afghan refugees, who left to neighboring countries during the conflict years, have returned to Kabul. Population growth has therefore led to urban expansion, even in the hilly topographies where environmental vulnerabilities are high.

Thus, rapid population growth and urban expansion remain a huge challenge for local government authorities in Kabul. The inability of the market to meet housing demand, limited planning capacity and uncontrolled development have meant that informal development of land and housing is a defining feature of urban expansion in Kabul city. Approximately 69 percent of the planned area of the city is occupied by informal settlements (World Bank, 2005; Kabul City Municipality, 2008). About 2.44 million residents reside in informal settlements (World Bank, 2005). Informal settlements are therefore pervasive and extensive.

Furthermore, conflicts, instability, urban insecurity and the general fragile political, economic and social situation has affected the implementation of the city's master plan prepared in 1978. As at 2002, only 20 percent of the master plan had been implemented (Habib, 2001; Viaro, 2004; JICA, 2011). Again, areas reserved for environmental conservation, safety, recreation, and undeveloped areas have been grabbed and sold to low-income migrants. These areas usually suffer from lack or access to infrastructures such as sewerage system and solid waste disposal service as well as inadequate access to public services like parks and playgrounds. Most importantly, many residents lack tenure 
to the lands they occupy.

In Kabul city, informal settlements are referred to as "Zorabad", which literally translates as "land taken by force". It refers to the areas where people grabbed government and public land and sold it to others or build their houses without seeking official permission. The official criteria are that houses are: 1) in violation of the master plan of Kabul, and 2) without meeting formal requirements for access to land (Gebremedhin 2005). Informal settlements in Kabul are complex and diverse in a variety of ways, such as their physical form, vulnerability, and location and socioeconomic characteristics of residents.

A detailed description of Kabul city's informal settlements has been analyzed in an earlier research, and a repetition here is therefore deemed unnecessary (See Nazire \& Kita, 2016). That said, such settlements in Kabul accommodate a wide range of social and economic groups of people. Settlements range from low to high densities and are located centrally in the city or sprawling at the edge of the city. Additionally, some houses are larger than in formal areas and have different compositions of both poor and rich (Bertaud, 2005).

Like many settlements in developing countries, informal settlements offer low-income residents a "right to the city", even though they suffer from inadequate access to infrastructure, public facilities, as well as being prone to flooding and other natural hazards (about $9.8 \%$ of informal houses).

\subsection{Overview of the Informal Settlement Upgrading in Kabul City}

In an attempt to confront the growing expanse of informal settlements in Kabul, the government of Afghanistan with support from international aid agencies (UN Habitat, World Bank, etc.) has introduced participatory upgrading programs. Considered as a "people process", the program is aimed at promoting community leadership and control in interventions with technical assistance from municipalities. The upgrading program is centered on improving infrastructure, securing land tenure and preserving historical districts.

The program is organized at three main levels: community, municipal and national levels. At the community level, families and residents form "community development councils" (CDC) are responsible for the design, implementation, and maintenance of projects (e.g. roads, drainages, and open spaces). Cities, such as Kabul, at the municipal level design development strategies and train their staff to work with local residents. The national level involves strategies, laws, and policies that support and strengthen upgrading processes at the local level.

The Kabul upgrading program is organized in five phases, involving fifteen strategic steps (Figure 1). Since its introduction in 2005, and some districts have been upgraded. It involved community consultations (mostly composed of men) to discuss neighborhood priorities. Communities, in the form of the CDC, contributed 10 - 15 percent of the project cost. The program also recognized each household right to security of tenure, access to public services and participation. 


\section{Research Methodology}

This study was conducted in Afshar area, located in District 5 (D5) within Kabul City (Figure 2). The population of this district is approximately 320,000 (2012 estimation). Most of the informal settlements in this district are located in flat and agriculture land while some are located on the mountain slopes. The areas located on flat land have mostly been upgraded. The Afshar area, one of the upgraded areas was purposively selected for this study for a number of reasons. First, compared to other informal areas which have been upgraded recently, the $A f$ shar area has been upgraded over past five years, which offers adequate time to analyses effects. Secondly, the land is located in a flat area, as compared to other informal areas, which made it much easier to access

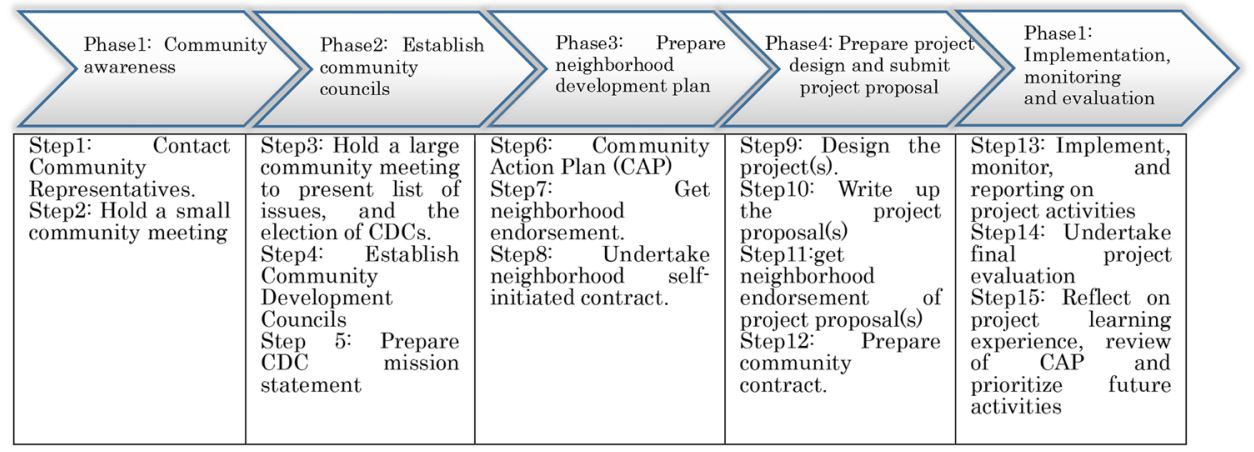

Figure 1. Community mobilization process (Source: UN-HABITAT 2009.

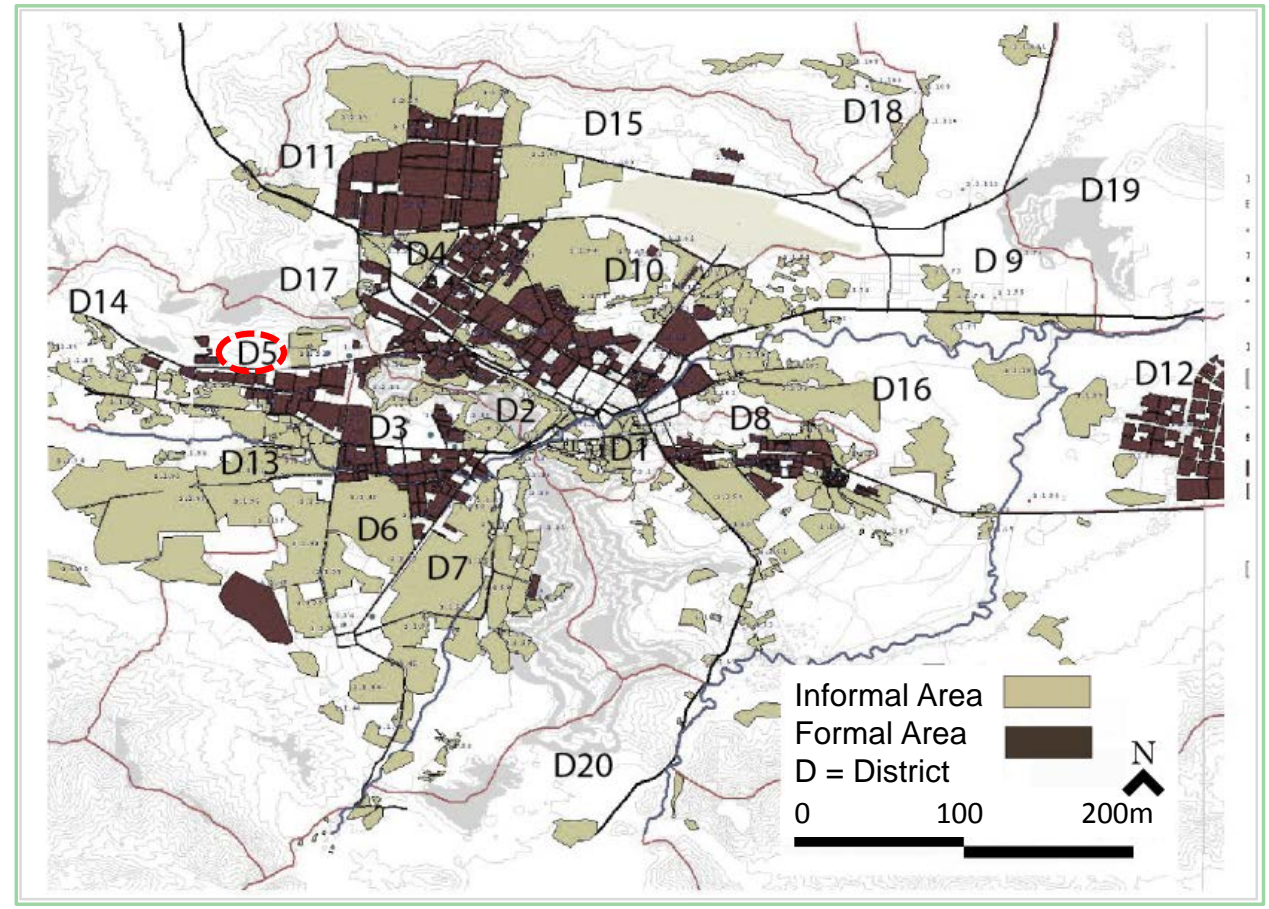

Figure 2. Location of study area in Kabul city map (Source: adapted from ministry of urban development, 2007). 
houses and interview residents. Thirdly, the agreement or cooperation of residents for their house to be surveyed (since the majority of people are not willing to survey their houses in Kabul city due to security issues). Fourth, the location of the area is near to the central part of the city which is preferred in view of security and safety considerations within Kabul city.

Semi-structured interviews were conducted in 94 houses in one neighborhood in $A f$ shar area. There was more than one household in some houses, one household head was selected in each of the 94 houses. To ensure that respondents had a better understanding before and after the upgrading, residents who had stayed in the house longest were interviewed. All the respondents were men, in according to local culture, where men are afforded the responsibility to provide such information. In cases where women were contacted, the researchers were directed to the male household head. In the absence of a head of the family, one male adult was selected as a representative. The questionnaire was designed to draw out information on; characteristics of houses and residents, houses, and neighborhood improvement before and after upgrading, the respondent's view and experience about the effect of upgrading and satisfaction with the physical environment in the area. In addition, observation of the area and photography was used to ascertain upgrading interventions and their effects. Content analysis and frequencies were used to analyze the data.

Moreover, interviews were conducted with representatives from the Kabul Municipality, Ministry of Urban Development and Community Development Councils. These enabled triangulation as well as understanding the mechanisms of the upgrading process.

\section{Results and Discussion}

\subsection{Characteristics of Residents and Study Area}

The average period of residence in the area is about 18 years, which provides enough period to understand conditions before and after the upgrading program. The majority of the residents were owner-occupiers (88\%), as compared to the rental population (12\%) (Table 1). In terms of employment, only 81 percent of the respondents were unemployed. More than half of the respondents were into individual private enterprises (59\%), which confirm earlier studies on informal settlements (Okyere \& Kita, 2016; Ojong, 2011; Jabeen, Johnson, \& Allen, 2010). However, as much as 31 percent of respondents in the informal areas were employed in the public and corporate sectors, which reinforces recent observations in the Middle East and Asia that there is an interweaving of formal-informal relations where workers in the formal sector could be found in informal settlements (AlSayyad, 2004; Roy, 2005, 2011).

In terms of the housing structure, majority of the houses were one-story (54\%), followed by two-story (30\%), three-story (11\%) and four-story (5\%). Plot sizes were quite large, ranging from 300 to $700 \mathrm{~m}^{2}$. In terms of building material, about 66 houses were made of timber roof and sun-dried brick walls. The remaining houses were built from concrete and burnt brick walls. Usually, residents rely on locally available materials, 
which are cheap and easily accessible, to construct houses. However, this also affects the quality of housing.

The study revealed that the main upgrading interventions in the area have been paving the streets and construction of drainage facilities aimed at improving the physical condition of the area. Additionally, electricity has been provided to all houses in the area. Thus, the upgrading program in the area has been minimal and physically oriented. The reason for this, as revealed during the institutional interviews, is due to financial constraints and the incremental nature of the upgrading program. In other words, the city has adopted a "piecemeal approach" in the implementation. In view of the evolution of upgrading programs to adopt an integrated approach which considers physical, social, recreational, environmental, economic, and institutional dimensions, it can be argued that the Afshar case is basic, lacks integration and fails to take a composite view of informal settlement improvement.

Table 1. Characteristics of houses in the study area (Source field survey, 2016).

\begin{tabular}{|c|c|}
\hline Characteristics & Percentage \\
\hline \multicolumn{2}{|c|}{ No of storey } \\
\hline Four storey & 5 \\
\hline Three storey & 11 \\
\hline Two storey & 30 \\
\hline One storey & 54 \\
\hline \multicolumn{2}{|c|}{ Occupancy status } \\
\hline Own & 88 \\
\hline Rent & 12 \\
\hline \multicolumn{2}{|c|}{ Size of plot/land } \\
\hline $300-400 \mathrm{~m}^{2}$ & 84 \\
\hline $500-600 \mathrm{~m}^{2}$ & 16 \\
\hline \multicolumn{2}{|c|}{ Quality of housing } \\
\hline Concrete roof + burned brick walls & 34 \\
\hline Timber roof + sun dried brick walls & 66 \\
\hline \multicolumn{2}{|c|}{ Residents year in the area } \\
\hline Less than 10 years & 31 \\
\hline Above 10 years & 69 \\
\hline \multicolumn{2}{|c|}{ Employment status } \\
\hline Gov. employee and company employee & 31 \\
\hline Private worker/labor & 59 \\
\hline Unemployed & 11 \\
\hline
\end{tabular}


This stands in marked contrast to Hasan's (2006) findings of a more holistic implementation of upgrading in Karachi, Pakistan, which includes economic, social and physical considerations. Thus, residents were quick to identify the limited upgrading interventions, with majority mentioning the need for playgrounds and parks in the settlement as a recreational and socializing facility for both kids and adults. The municipality, on the other hand, indicated that aside from the constraints mentioned earlier, there was no land available for facilities like parks and playgrounds, as residents tend to build in an uncontrolled manner, grabbing land without any reservation for public facilities.

Even though upgrading interventions have been minimal, respondents have access to sanitation and water. Piped water did not exist in the settlement; rather all residents rely on privately dug wells and hand-pumps, which is not uncommon in several parts of Kabul city. Again, even four years after upgrading, local schools, and clinics are not available in the settlement. Respondents cover an average of 20 minutes by car to access such facilities outside the settlement.

\subsection{Effect of Upgrading}

The study also sought to understand the effects of the upgrading program in the Afshar informal area. This was considered in terms of housing improvement, accessibility, and local economy (small business and stores). In order to identify the effects of the upgrading program, respondents were given two-time frames: 2002 to 2012 and 2012 to 2016. The year 2012 was the reference point since the settlement was upgraded in 2012. These two-time frames provided a reference to understand the before and after situation and thus, analyze effects.

Though minimal in its implementation, residents alluded to some positive effects of the upgrading program in their settlement. Consequently, this section is dedicated to understanding these effects in light of results from the survey

\subsubsection{Effect of Upgrading on Houses Improvement}

One of the critical initiatives in informal settlement upgrading is housing, especially in terms of quality. Interview with residents indicated that the city upgrading program did not provide any specific housing improvement support. Housing improvements were done by residents themselves. As indicated in Figure 3, before upgrading (2002-2012), no significant activities had been done to improve the quality of housing. There were occasional repair and extension works to fix minor problems such as cracks and damages and house extensions for increasing household size. On the other hand, after the upgrading the areas (2012-2016), there appeared significant changes in house improvement (Figure 4). The proportion of residents who had made improvements to their houses had increased from 22 percent to 60 percent. Out of this, majority repaired their houses $(36.2 \%)$ or repaired and extended through additional floors to the existing house $(7.4 \%)$. Others have completely reconstructed their houses (16\%).

Contrary to house improvements before upgrading, residents indicated that upgrading 
had improved the appearance of their settlement. They explained that were self-motivated to improve the conditions of their houses to match the "new" neighborhood improvements. Thus, modernizing the house-in terms of aesthetics, use of modern material like tiles, glass and concrete and facilities like flash toilets-increased from 10 (before upgrading) to 25 percent (Figure 5 and Figure 6). Again, residents intimated that these attracted new residents into the neighborhood. They consequently were taking

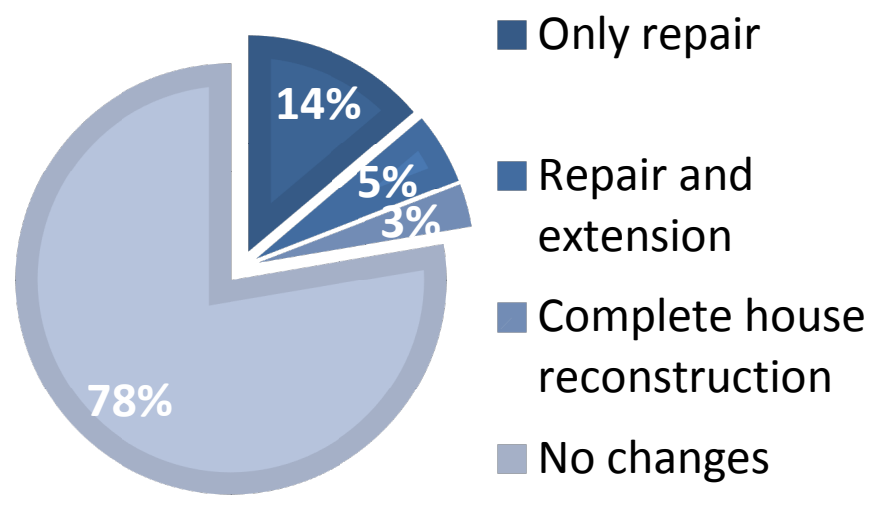

Figure 3. Houses improvement before upgrading (2002-2012) (Source: Field survey, 2016).

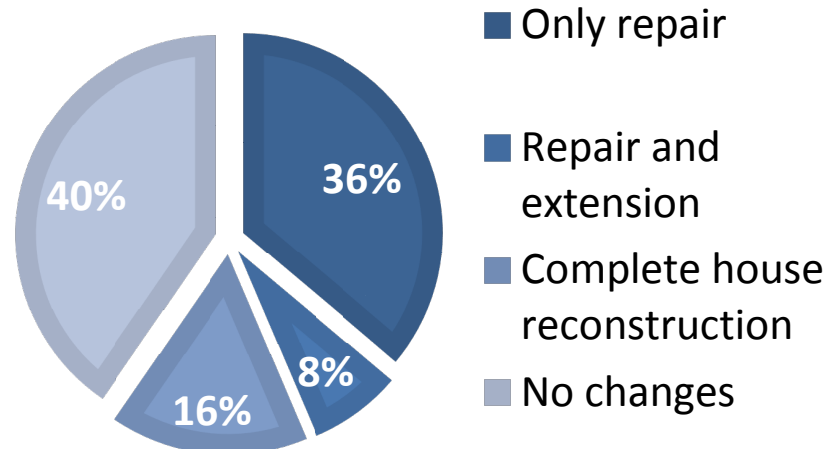

Figure 4. Houses improvement after upgrading (2012-2016) (Source: Field survey, 2016).

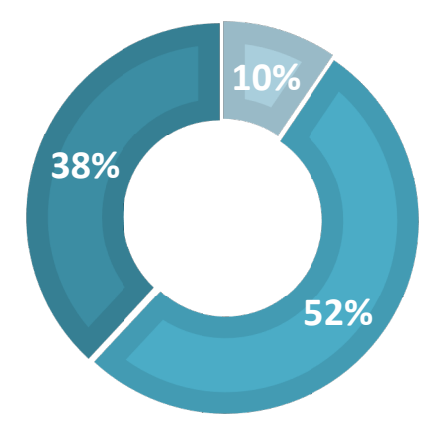

Modernize the house

Repair damages

Increase in the number of family

Figure 5. Reason for changes 2002-2012 (Source: Field survey, 2016). 


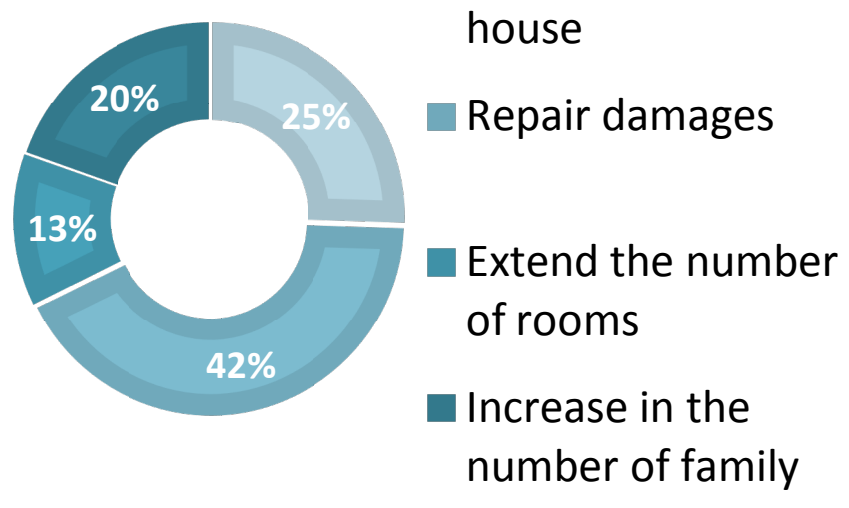

Figure 6. Reason for changes 2012-2016 (Source: Field survey, 2016).

advantage of the opportunity to extend their houses to rent to these new residents. This explains why after the upgrading, 13 percent of interviewed residents had extended their houses. Together, these factors are leading to the gradual disappearance of traditional, single-storey, low-quality houses in the settlement to "modernized" houses (see Figure 7).

This suggests settlement upgrading can have a positive influence on resident's house improvement practices. It points to Turner's (1974) "self-help" initiatives in housing and neighborhood improvement, and that resident's possess the ability to foster meaningful changes in improving the deplorable housing conditions common in informal settlements in developing countries. It also confirms research findings in other cities in Afghanistan like Kandahar (Turkstra \& Popal, 2010) that settlement upgrading contributes to self-build improvement activities in housing.
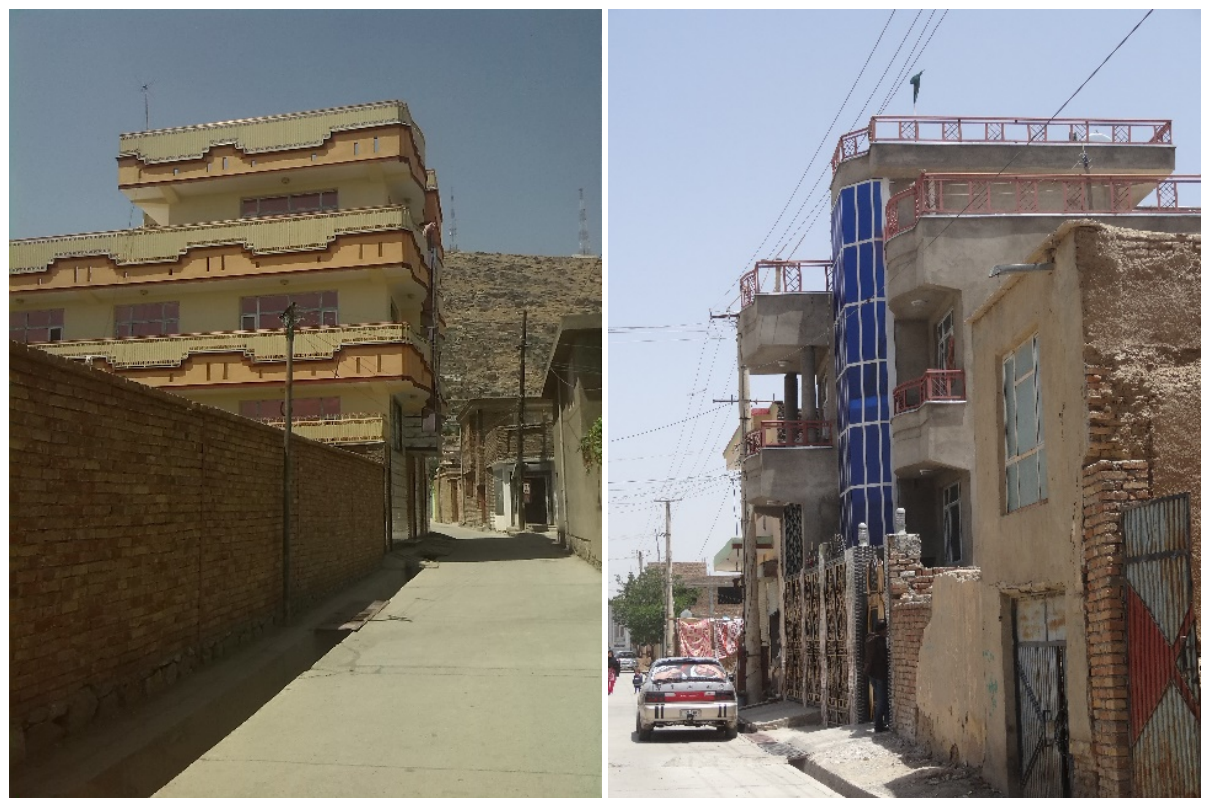

Figure 7. Houses improvement in the study area (Author's own picture 2016). 


\subsubsection{Effect of Upgrading on the Accessibility of the Area}

Surface accessibility is very important in informal settlements as there are often times limited alternative modes of transport to different parts of the settlement or the larger city.

Another effect of settlement upgrading that emerged from the interviews is the issue of road accessibility in the Afshar area. Before upgrading, household's mentioned that their area was highly inaccessibility in the rainy seasons. During the period of heavy rains, which occur annually, roads were flooded and not accessible. Again, the lack of roads on main access routes implied that both walking and vehicular access was a huge challenge in the rainy days (Figure 8). As indicated earlier, most facilities like schools, clinic/hospital, and other economic facilities were located outside the settlement. Before upgrading, it took local residents an average distance of approximately 20 minutes by car to access such basic facilities in a nearby settlement. The fare cost for this is about 80 AFN (1.2US\$ October 2016).

The construction of drainage facilities and the paving of all streets in the Afshar areas has greatly impacted accessibility after upgrading. Interviews revealed that roads are accessible at all times of the year. The majority of residents mentioned that average distance to access facilities in the nearby settlement has reduced from 20 to 10 minutes. The cost of vehicle transport (usually taxi service) has also reduced 80AFN (1.2US\$) to 50AFN (0.8US\$). Observations during the survey showed children playing on the streets, adult residents chatting across and more residents walking, even during the rainy days.

This finding corresponds to Gouverneur's (2015) claim that informal settlement upgrading has proven to improve mobility and accessibility and enhanced informal settlements access to critical services and facilities-both internally and externally. It also
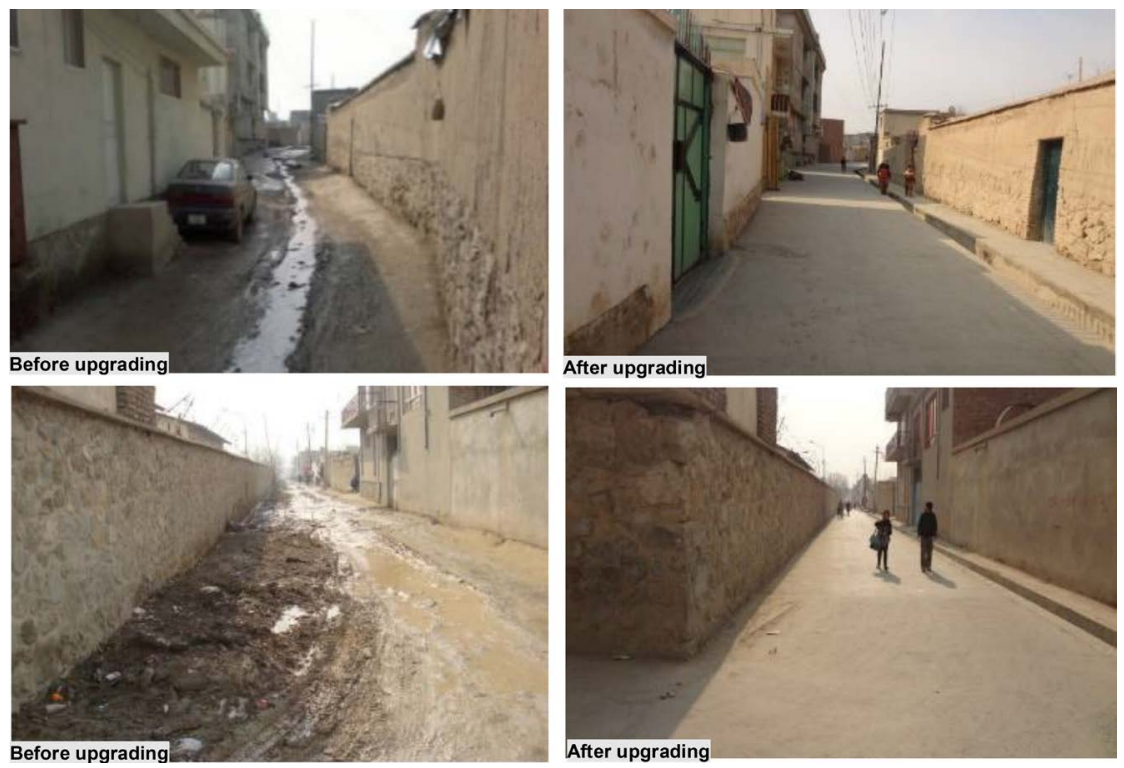

Figure 8. Streets and drainage improvement (Source: Kabul Municipal Development Program 2016). 
implies that settlement upgrading has the possibility to alter human behavior, in this case encouraging walking and increasing social use of paved roads within the neighborhoods.

\subsubsection{Effect of Upgrading on Local Economy}

It has become quite clear that small-scale non-formalized economic activities (informal sector) are inseparable from the socio-spatial organization of residents in informal settlements. This study found the existence of commercial activities like home-based shops in informal settlements in Kabul, including the Afshararea.

The survey revealed that local economic activities have intensified in the area following the upgrading of the settlement. Before the upgrading, they were few shops and most of them were home-based economic activities. However, during the survey, there were several mixed-used developments in the area. Out of the 46 percent of households who were living in more than one storey dwellings, about 10.5 percent have turned the first floor into stores. These stores usually trade in domestic goods, grocery and a limited amount of electrical goods serve two important purposes: providing a source of income for the owners and renters and helping to improve residents' access to basic goods in the neighborhood. Such mixed-use (commercial and residence) activities exist in several parts of the Afshararea, especially in multi-story housing transformations (Figure 9 and Figure 10). The motivation for such new 'developments', according to residents is to take advantage of the new improvements in the area and the increase in residents due to the upgrading program.

Again, $68 \%$ of interviewees also indicated that before, the condition of roads did not make such local economic activities feasible. Prior to the upgrading program, shop owners indicated that the dusty road meant they had to clean their products frequently or close the shops during the rainy season. However, with improved road conditions and improved accessibility, local residents were patronizing such shops and commercial centers. These shops and small economic activities have become vital to the local economic base of the Afshar area. It points to the fact that settlement upgrading does not only encourage resident investment in their house but also into small scale commercial activities that can have a positive effect on the local economy in the long run. As Horen (2004) has revealed in a number of case studies in Asia, upgrading programs have had the long effect on the local economic basis of informal settlements. The case of Afshar, thus, affirms that settlement improvement encourages house owners to make investments that support the local economy.

\subsubsection{Satisfaction and Perceptions of Change within the Neighborhood}

This part of the paper focuses on the composite effect of house improvement, surface accessibility, and local economic activities on resident's satisfaction with the settlement upgrading. Residents were asked to choose satisfied or dissatisfied based on the physical improvements, accessibility, and the introduction of shops and other commercial services. From the results, 91 percent of interviewed residents were satisfied with improvements and current conditions in the settlement (Figure 11). 


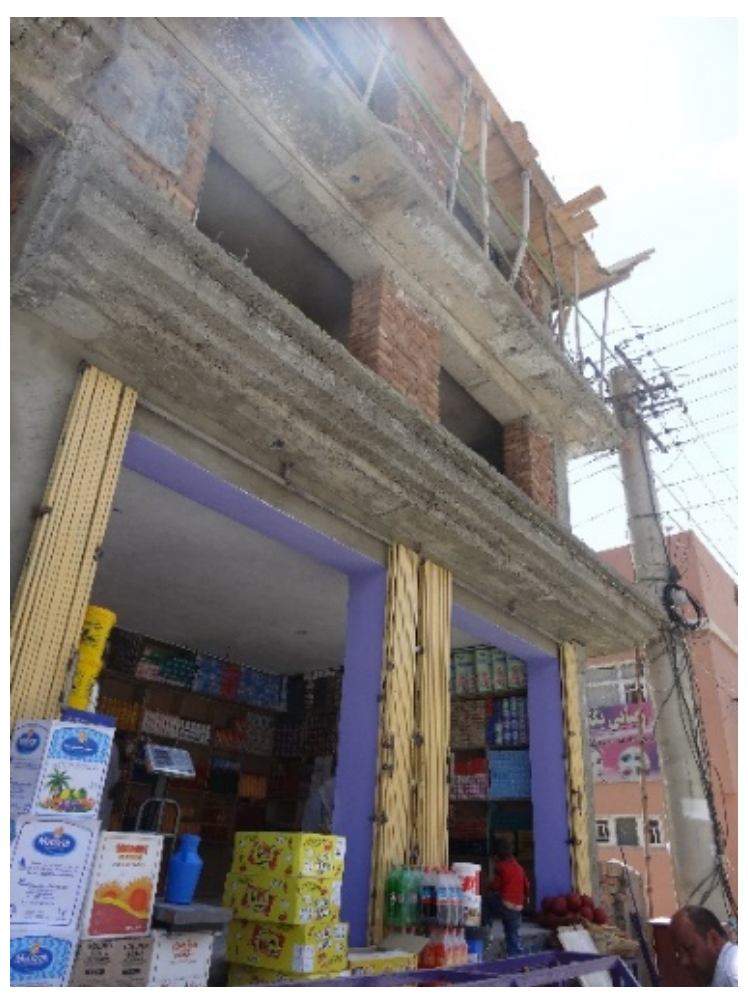

Figure 9. New shops in new Multi-story housing Author's own picture 2016.

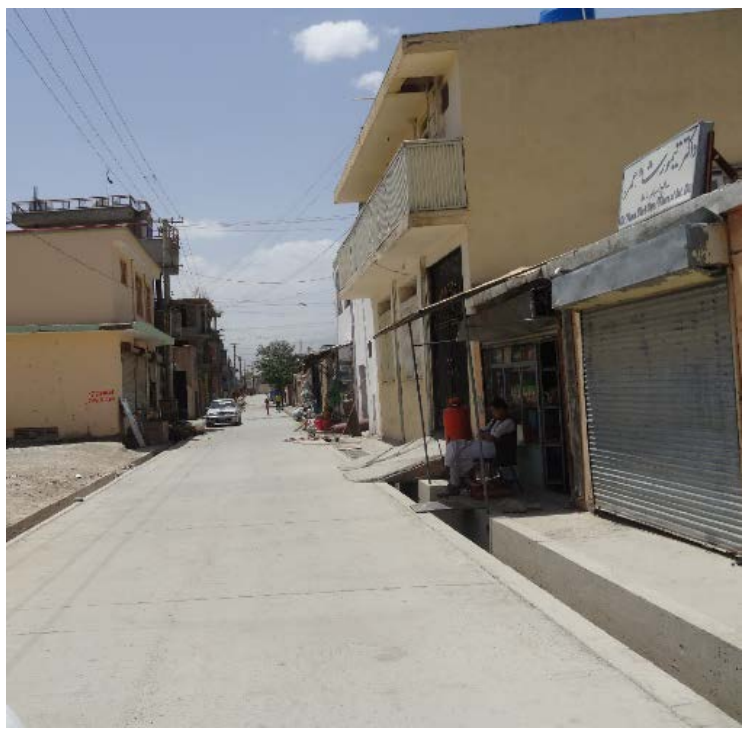

Figure 10. New shops along improved roads Author's own picture 2016.

For those who were satisfied, they assert that the physical appearance of the settlement has greatly improved with the introduction of drainage facilities, sewer, road pavement, and individual efforts to improve the physical condition of their houses. The reasons for this positive experience is due to improved accessibility and decrease in cost 
of taxi fares (55.3\%), improved environment (21.3\%), available new social space for kids to play and adults to chat (17\%), and the new shops and commercial activities that has improved access to basic goods and services (6.4\%) (Table 2).

On the other hand, a few of the residents were unsatisfied (8\%) with the upgrading for a couple of reasons. The two main reasons were the lack of public or open spaces for recreation and social facilities such as, park and playground clinics, schools, and among others. Residents lamented the lack of open spaces for recreation, which they underlined as important in improving social connections and enhancing security in the area. Even though accessibility has improved, respondents maintained that the lack of improved water and facilities affected their overall experience and comfort in the area. This is so because the majority of the residents continue to depend on hand-dug wells which are not always reliable. The rationale for respondent's dissatisfaction points to the limited nature of the upgrading program, which focused on physical improvements without adequate interventions to public facilities that can foster social and environmental improvements in the Afshar area. It defeats the general government policy of integrated informal settlement upgrading, which in the case of Afshar, is non-existent.

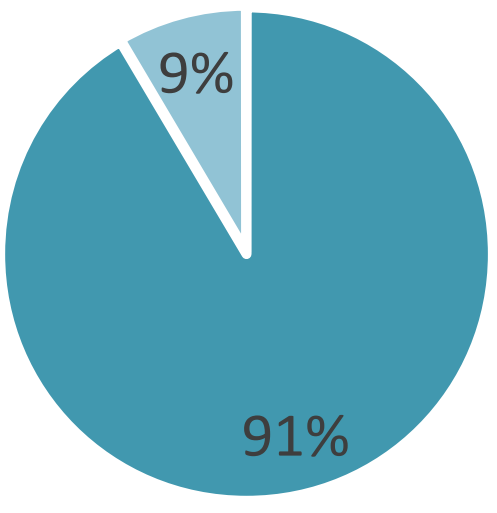

\section{Satisfied Dissatisfied}

Figure 11. Resident's satisfaction (Field survey, 2016).

Table 2. Reasons for Satisfaction (Field Survey, 2016).

\begin{tabular}{cc}
\hline Reasons for satisfaction with the neighborhood & Valid (\%) \\
Supported social gathering & 2.1 \\
Improved local economy & 6.4 \\
Taxi cost cheaper11 & 11.7 \\
Created space for children to play & 14.9 \\
The physical condition of the area has improved & 21.3 \\
Improved accessibility & 43.6 \\
\hline
\end{tabular}




\section{Conclusion}

Kabul city currently faces a daunting task of addressing the challenge of urban informality. The volatile security situation, post-war urban rapid migration and urbanization, land grabbing and limited government capacity to provide affordable housing meant that informal settlements have become the mainstay of the majority of urban residents in Kabul. In response, the Afghan government with support from international development agencies implemented a settlement upgrading program. This study has attempted to understand the government's upgrading program and its effects within the Afshar area in Kabul city.

There are two fundamental findings from the study. First, the upgrading program in Kabul is limited, piecemeal and concentrated on physical improvements. Thus, drainage, pavement, sewer among others have been the main interventions. The project thus lacks the needed integration that has characterized recent innovations in upgrading in neighboring countries such as Pakistan, and India. Second, the upgrading programs have encouraged individual house improvements, investment in local economic activities and enhanced vehicular accessibility and the social use of the street. This shows that in spite of its limitations, upgrading is still useful as a strategy for improving informal settlements.

The preceding discussions suggest a need to critically rethink the upgrading interventions in Kabul city and other cities in Afghanistan. It demonstrates the need to consider all dimensions of informal settlement living: social, economic, ecological, institutional and spatial. There is also the need to build the capacity of local government institutions to foster the effectiveness of these interventions. It also requires the need to encourage collaborative and participatory planning, crucial to promoting peace and harmony. The fact that there is limited space for open spaces in the settlement point to the need for land readjustment experimentation in the area and needs for conversion of existing structures to the public spaces like park and playground. There are on-going discussions to employ land readjustment and these findings from this study further reinforce its significance.

Looking into the future, further research is needed to comprehensively understand the socio-spatial and political structure of informal settlements in Kabul city and how community-led strategies can be developed to promote locally based interventions. The future then should look at civil society and community organizations' role in informal settlement upgrading. This will be beneficial to the spatial and social development of informal areas, but also in promoting peace and security.

\section{References}

Abbott, J. (2002). An Analysis of Informal Settlement Upgrading and Critique of Existing Methodological Approaches. Habitat International, 26, 303-315. https://doi.org/10.1016ccccc/S0197-3975(01)00049-2

Acioly, C. (2002). The Rationale of Informal Settlements Regularization Projects: from Settlement Upgrading to Integration Approaches. Lecture Notes. Rotterdam: Institute for Housing and Urban Development Studies. 
AlSayyad, N. (2004). Urbanism as a "New" Way of Life. In A. Roy, \& N. AlSayyad (Eds.), Urban Informality: Transnational Perspectives from the Middle East (pp. 7-30). South Asia and Latin America.

Balbo, M. (2001). Shelter: Emerging Trends and Policies. Habitat Debate, 7, 6-7.

Beall, J., \& Esser, D. (2005) Shaping Urban Futures: Challenges to Governing and Managing Afghan Cities. Kabul: Afghanistan Research and Evaluation Unit (AREU).

Bertaud, A. (2005). Urban Land Management in Afghanistan Kabul Urban Development Current City Structure (pp. 2-30). Spatial Issues, Recommendations on Urban Planning.

Boonyabancha, S. (2009). Land for Housing the Poor-By the Poor: Experiences from the Baan Mankong Nationwide Slum Upgrading Programme in Thailand. Environment and Urbanization, 21, 309-329. https://doi.org/10.1177/0956247809342180

Boonyabancha, S. (2005). Baan Mankong Going to Scale with "Slum" and Squatter Upgrading in Thailand. Environment and Urbanization, 17, 21-46.

Burra, S. (2005). Towards a Pro-Poor Framework for Slum Upgrading in Mumbai, India. Environment\& Urbanization, 17, 67-88. https://doi.org/10.1177/095624780501700106

Davis, M (2004). Planet of Slums: Urban Involution and the Informal Proletariat. New Left Review, 26, 5-34.

Durand-Lasserve, A., \& Royston, L. (2002). Holding Their Ground: Secure Land Tenure for the Urban Poor in Developing Countries (264 p). London: Earthscan Publications.

Galuszka, J. (2014). Community-BASED Approaches to Settlement Upgrading as Manifested through the Big ACCA Projects in Metro Manila, Philippines. Environment and Urbanization, 26, 276-296. https://doi.org/10.1177/0956247813517850

Gebremedhin, Y. (2005). Preliminary Assessment of Informal Settlements in Kabul City (pp. 3-6). http://www.terrainstitute.org/pdf/Informal settlement yohannes.pdf

Gilbert, A. (2007). The Return of the Slum: Does Language Matter? International Journal of Urban and Regional Research, 31, 697-713. https://doi.org/10.1111/j.1468-2427.2007.00754.x

Gouverneur, D. (2015). Planning and Design for Future Informal Settlements: Shaping the SelfConstructed City. London: Routledge.

Habib, J. (2011). Urban Cohesiveness in Kabul City: Challenges and Threats. International Journal of Environmental Studies, 68, 363-371. https://doi.org/10.1080/00207233.2011.578338

Hasan, A. (2006). Orangi Pilot Project: The Expansion of Work beyond Orangi and the Mapping of Informal Settlements and Infrastructure. Environment \& Urbanization, 18, 451-480.

https://doi.org/10.1177/0956247806069626

Horen, B. V. (2004). Community Upgrading and Institutional Capacity Building to Benefit the Urban Poor in Asia. In Forum on Urban Infra-Structure and Public Service Delivery to the Urban Poor, Regional Focus: Asia (pp. 1-30). Washington, DC: Woodrow Wilson International Center for Scholars (WWIC).

Huchzermeyer, M. (2004). Unlawful Occupation: Informal Settlements and Urban Policy in South Africa and Brazil. Trenton, NJ: Africa World Press.

Imparato, I., \& Ruster, J. (2003). Slum Upgrading and Participation: Lessons from Latin America. Washington DC: World Bank. https://doi.org/10.1596/0-8213-5370-5

Jabeen, H., Johnson, C., \& Allen, A. (2010). Built-in Resilience: Learning from Grassroots Coping Strategies for Climate Variability. Environment and Urbanization, 22, 415-431. https://doi.org/10.1177/0956247810379937

JICA (2011). Promotion of Kabul Metropolitan Area Development: Capacity Development Project (pp. 1-103). Kabul City Current Status Report for Urban Development. 
Kabul City Municipality (2008). Making Cities More Economically Productive and More Equitable. Urban Development, 11, 15-23.

Khalifa, M. A. (2015). Evolution of Informal Settlements Upgrading Strategies in Egypt: From Negligence to Participatory Development. Ain Shams Engineering Journal, 6, 1151-1159. https://doi.org/10.1016/j.asej.2015.04.008

Kudva, N., \& Beneria, L. (2005). Rethinking Informalization: Poverty, Precarious Jobs and Social Protection. Ithaca: Internet First University Press. http://hdl.handle.net/1813/3716

Kudva, N. (2009). The Everyday and the Episodic: The Spatial and Political Impacts of Urban Informality. Environment and Planning A, 41, 1614-1628. https://doi.org/10.1068/a41101

Lieberherr-Gardiol, F. (2006). Slums Forever? Globalisation and its Consequences. The European Journal of Development Research, 18, 275-283. https://doi.org/10.1080/09578810600709484

Lombard, M. (2014). Constructing Ordinary Places: Place-Making in Urban Informal Settlements in Mexico. Progress in Planning, 94, 1-53. https://doi.org/10.1016/j.progress.2013.05.003

Menshawya, A. E., Alya, S. S., \& Salmana, A. M. (2011). Sustainable Upgrading of Informal Settlements in the Developing World, Case Study: Ezzbet Abd El Meniem Riyadh, Alexandria, Egypt. Procedia Engineering, 21, 168-177. https://doi.org/10.1016/j.proeng.2011.11.2001

Nazire, H., \& Kita, M. (2016). Specifying Characteristics of Informal Settlements by Comparing Four Areas from the Aspects of Houses, Land Tenure and Social Factors in Kabul, Afghanistan. Journal of Architecture and Planning, 81, 2197-2206. https://doi.org/10.3130/aija.81.2197

Noori, A. W. (2010). Challenges of Traffic Development in Kabul City. Unpublished PhD Dissertation, Mathematik und Informatik, Physik, Geographie Institutfür Geographie, Gießen: Justus-Liebig-Universität Gießen.

Ojong, N. (2011). Livelihood Strategies in African Cities: The Case of Residents in Bamenda, Cameroon. African Review of Economics and Finance, 3, 8-25.

Okyere, A. S., \& Kita, M. (2015). Rethinking Urban Informality and Informal Settlements Growth in Urban Africa: A Literature Discussion. Journal of Sustainable Development in Africa, 17, 101-124.

Okyere, A. S., Aramburu, K., Kita, M., \& Nazire, H. (2016). COFOPRI's Land Regularisation Program in Saul Cantoral Informal Settlement: Processes, Results and the Way forward. Current Urban Studies, 4, 53-68. https://doi.org/10.4236/cus.2016.41005

Roy, A. (2005). Urban Informality: Toward an Epistemology of Planning. Journal of the American Planning Associarion, 71, 147-158. https://doi.org/10.1080/01944360508976689

Roy, A. (2011). Slumdog Cities: Rethinking Subaltern Urbanism. International Journal of Urban and Regional Research, 35, 223-238. https://doi.org/10.1111/j.1468-2427.2011.01051.x

Smolka, M. O., \& Biderman, C. (2011). Housing Informality: An Economist's Perspective on Urban Planning. Lincoln Institute of Land Policy Working Paper.

The Guardian (2014). Kabul-The Fifth Fastest Growing City in the World-Is Bursting at the Seams.

https://www.theguardian.com/cities/2014/dec/11/kabul-afghanistan-fifth-fastest-growing-cityworld-rapid-urbanisation

Turkstra, J., \& Popal, A. B. (2010). Peace Building in Afghanistan through Settlement Regularization, Settlement Regularization Afghanistan. In 46th ISOCARP Congress (pp. 1-13). Netherlands: International Society of City and Regional Planners.

UN Habitat (2003). The Challenge of Slums. Global Report on Human Settlements, Nairobi: Human Settlement Programme. 
Viaro, A. (2004). What Is the Use of a Master Plan for Kabul? In Development of Kabul: Reconstruction and Planning Issues. In 10th Architecture \&Behaviour Colloquium (pp. 153-163). Zurich: Federal Institute of Technology.

Wegelin, E. A. (2004). Informal Settlements and their Upgrading: Building on the Lessons of Three Decades of Experience. In Ministerial Conference on Informal Settlements in South Eastern Europe (pp. 237-342). Paris: Encyclopedia of life support system (EOLSS).

Wekesa, B. W., Steyna, G. S., \& Otieno, F. A. O. (2011). A Review of Physical and Socio-Economic Characteristics and Intervention Approaches of Informal Settlements. Habitat International 35, 238-245. https://doi.org/10.1016/j.habitatint.2010.09.006

Weru, J. (2004). Community Federations and City Upgrading: The Work of Pamoja Trust and Muungano in Kenya. Environment and Urbanization, 16, 47-62. https://doi.org/10.1177/095624780401600105

World Bank (1974). Sites and Service Projects. Washington DC.

World Bank (2005). Kabul Urban Policy, Why and How Should Kabul Upgrade Its Informal Settlements: A Policy Note (pp. 1-8).

http://siteresources.worldbank.org/SOUTHASIAEXT/Resources/223546-1150905429722/Polic yNote2.pdf

World Bank (2016). World Development Indicators. Washington: The World Bank.

\section{Submit or recommend next manuscript to SCIRP and we will provide best service} for you:

Accepting pre-submission inquiries through Email, Facebook, LinkedIn, Twitter, etc. A wide selection of journals (inclusive of 9 subjects, more than 200 journals)

Providing 24-hour high-quality service

User-friendly online submission system

Fair and swift peer-review system

Efficient typesetting and proofreading procedure

Display of the result of downloads and visits, as well as the number of cited articles

Maximum dissemination of your research work

Submit your manuscript at: http://papersubmission.scirp.org/

Or contact cus@scirp.org 